\title{
Syndicate Women
}

Gender and Networks in Chicago Organized Crime

CHRIS M. SMITH

甲

University of California Press 
University of California Press, one of the most distinguished university presses in the United States, enriches lives around the world by advancing scholarship in the humanities, social sciences, and natural sciences. Its activities are supported by the UC Press Foundation and by philanthropic contributions from individuals and institutions. For more information, visit www.ucpress.edu.

University of California Press

Oakland, California

(C) 2019 by Chris M. Smith

Library of Congress Cataloging-in-Publication Data

Names: Smith, Chris M., author.

Title: Syndicate women : gender and networks in Chicago organized crime / Chris M. Smith.

Description: Oakland, California : University of California Press, [2019] | Includes bibliographical references and index. |

Identifiers: LCCN 2018057020 (print) | LCCN 2018059706 (ebook) | ISBN 9780520972001 (e-book) | ISBN 9780520300750 (cloth : alk. paper) | IsBN 9780520300767 (pbk : alk. paper)

Subjects: LCSH: Organized crime-Illinois—Chicago—2oth century. | Female offenders-Illinois-Chicago-2oth century.

Classification: LCC HV6795.C4 (ebook) | LCC HV6795.C4 5652019 (print) | DDC 364.106082/0977311-dc23

LC record available at https://ccn.loc.gov/2018057020

Manufactured in the United States of America

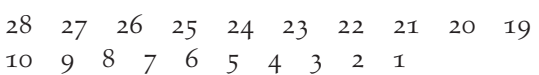

$\begin{array}{llllllllll}10 & 9 & 8 & 7 & 6 & 5 & 4 & 3 & 2 & 1\end{array}$ 
Syndicate Women 
The publisher and the University of California Press Foundation gratefully acknowledge the generous support of the Richard and Harriett Gold Endowment Fund in Arts and Humanities. 
For Sis 
Heroines of the booze mobs, the gun-molls of a cock-eyed era labeled prohibition, some day may emerge as a composite, legendary figure in literary form worthy of becoming a prominent part of American folklore. This epic gun-moll will be the modern Maid Marian of rollicking songs in which her man, the hero, will be an amazing character, pictured as pirate, gorilla, and great lover, rolled into one. The story will tell how the hero's machine guns mowed down enemies like blades of wheat before a sickle until, one day, he was "taken for a ride." At this point the gun-moll will take the spotlight in a finale of tears, wailing before an officious but future person labeled law.

Joseph u. Dugan, "Gang Women of Dry Era Bid for Spurious Fame," Chicago Daily Tribune, December 31, 1933, G3. 